\section{Nasjonalforeningen om seg selv}

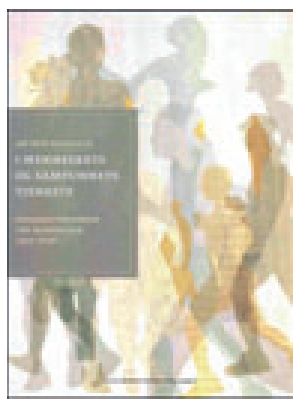

\section{Jan Erik Grindheim}

I menneskets og samfunnets tjeneste

Nasjonalforeningen for folkehelsen

1910-2010. 392 s, tab, ill. Oslo:

Universitetsforlaget, 2010. Pris NOK 449

ISBN 978-82-15-01581-1

Nasjonalforeningen for folkehelsen har fylt 100 år, og den har fått sin jubileumsbok, skrevet av Jan Erik Grindheim, som har bred forskningserfaring vedrørende frivillige organisasjoners historie.

Dette er en detaljert og påkostet bok. Illustrasjonene er mange og gode. Noteapparatet er omfattende og underbygger teksten med henvisning til dokumenter, intervjuer og annet. Jeg hadde likevel ønsket meg en litteraturliste, slik at det hadde vært enklere å finne frem til det forfatteren har brukt av annen litteratur på området. Person- og sakregister er imidlertid gode.

Forfatteren følger foreningen fra den ble til i 1910 og hadde tuberkulosen som hovedanliggende, og videre inn i perioden etter 1950 da det skjedde en nyorientering mot oppgaver som hjertesykdommer og eldreomsorg. Siste del omhandler perioden 1980-2010 og er kalt Mellom stat og marked, fordi betingelsene for foreningens drift på mange måter endret seg i denne tiden. Nasjonalforeningen har fått et grundig tilbakeblikk inn i sin fortid, egnet for selvrefleksjon ved jubileet.

Dessverre er det noen unøyaktigheter her og der. Det gjelder f.eks. historien om Reknes hospital (s. 32). At Robert Koch (1843-1910) i 1882 uttalte at tuberkulose bare kunne bekjempes med offentlige tiltak, var nok viktig. Men dette var velkjent og gammel kunnskap på denne tiden. Kochs banebrytende innsats i 1882 var at han identifiserte tuberkelbasillen (s. 26). Hvem er Ernst Holm (s. 31)? Det er nok legen og innovatøren Ingebrigth Christian Lund Holm (1844-1918) forfatteren mener, gründeren bak sanatorier i Holmenkollåsen, dr. Holms hotell på Geilo og mye annet. Og det heter altså tuberkulose med $u$, ikke tuberkolose, slik det står to ganger i figuren på side 55. Denne typen rusk som man oppdager umiddelbart, svekker tilliten til presisjonen, og man lurer på hva man ikke oppdager.

Den største innvendingen mot dette jubileumsskriftet går imidlertid på forfatterens plassering av jubilanten inn i sin kontekst. Som bakgrunn beskriver han norsk helsehistorie de siste hundre årene. Det er greit og bra. Utviklingen i norsk folkehelse er fortellingen om en ganske dramatisk forbedring, og den kan ikke fortelles ofte nok til nye generasjoner. Men hvilke mekanismer lå bak de positive omveltningene? Da er det nødvendig å trekke frem et bredt spektrum av forklaringer, der de økonomiske og politiske forklaringene sannsynligvis er langt viktigere enn mange andre, og hvor medisinsk vitenskap i en lang periode først og fremst tjente som premissleverandør. På slutten av 1800-tallet da tuberkulose og andre infeksjonssykdommer herjet som verst, hadde vi et klassedelt, liberalistisk samfunn, hvor veien mot allmenn velferdsøkning og bedre folkehelse åpenbart gikk via politisk innsats og fellestiltak, derunder opprettingen av organisasjoner for å ta opp kampsaker. Nasjonalforeningen ble dannet i 1910 og var en del av dette.

Men Nasjonalforeningen var ikke alene. På tross av at forfatteren viser til Norske Kvinners Sanitetsforening og litteraturen om den, underkommuniserer han at det var denne foreningen som var pioneren. Den skiftet virkeområde fra tradisjonell sanitet til tuberkulose da det viste seg at krigen mot Sverige uteble. Norske Kvinners Sanitetsforening ble en landsdekkende grasrotbevegelse med sprengkraft på mange områder. For samfunnet var fortsatt klassedelt, og sanitetskvinnene representerte folket og kvinnesaken, mens
Nasjonalforeningen og den tredje viktige aktøren, Norges Røde Kors, ble assosiert med legestanden og de høyere sjiktene. Sofie Rogstad har skrevet en tankevekkende artikkel om dette (1). Den bør leses som et korrektiv. Denne striden er viktig, fordi den kom til å prege det norske tuberkulosearbeidet $\mathrm{i}$ betydelig grad. I Norge fikk vi en tuberkuloseomsorg nedenfra. Enkel og nøktern, ja vel, men det ble et folkeansvar å bekjempe tuberkulose i alle lag av folket og med alle midler. Vi unngikk kontinentets kultur med de snobbete sanatoriene for de rike.

Opp gjennom Nasjonalforeningens historie var det en stadig revirmarkering overfor andre organisasjoner på folkehelseområdet. Nasjonalforeningen hadde imidlertid alltid en rekke av norsk medisins største navn i ledende posisjoner. Foreningen hadde også en formalisert tilknytning til helsemyndighetene ved at helsedirektøren satt i sentralstyret. Denne avtalen ble sagt opp av helsedirektøren 14. desember 1994.

For denne anmelderen er Grindheims bok om Nasjonalforeningen for mye av et festskrift som er kamuflert som helse- og sosialhistorie. Nasjonalforeningen har ikke eksistert i en boble.

\section{Øivind Larsen}

Institutt for helse og samfunn

Universitetet i Oslo

Litteratur

. Rogstad S. Kampen om eiendomsretten til tuberkulosesaken: om å søke næring av tæring. Historisk Tidsskrift 1996; 76: 87-116.

\section{Ei moderne andaktsbok}

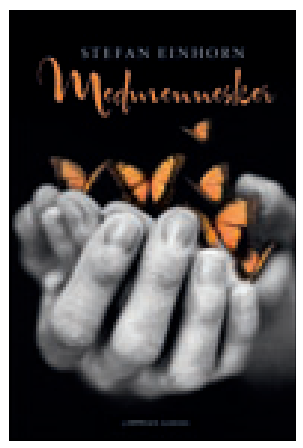

\section{Stefan Einhorn} Medmennesker

205 s. Oslo: Cappelen Damm, 2011.

Pris NOK 299 ISBN 978-82-02-33734-6

Ein del sanningar er så sjølvsagte at vi nettopp av den grunn har lett for å gløyme dei. Ei slik sanning er det at vi alle er medmenneske. Frå før fødselen til etter vår død betyr vi noko for andre menneske. Denne boka handlar om nettopp det. Forfattaren er professor ved Karolinska Institutet og overlege ved Radiumhemmet. Han er opptatt av etikk, har hatt stor suksess med bøkene Kunsten å vare snill (1) og Veier til visdom (2), og blir ofte nytta som føredragshaldar i Sverige.

Denne boka er verken ei fagbok, ei essaysamling eller ei novellesamling. Den vender seg til eit allment publikum, er lettlesen, narrativ i si form, fortel fiktive historier som forfattaren så reflekterer over, til saman tolv lesestykke. Sjølv om innhaldet ikkje er spesifikt religiøst, får eg assosiasjonar til ei god, gammaldags andaktsbok.

Her er verken emne- eller stikkordregister. Ingen illustrasjonar, få referansar til annan litteratur. Store emne blir omhandla, nærast på ein stikkordprega måte: Vi er våre relasjonar, mennesket er både godt og vondt, vi kan ikkje bestemme på førehand kva konsekvensar våre handlingar vil få, det er stor kraft i å tilgi, det både lønner seg og er naturleg for dei fleste menneske å vere gode mot kvarandre. Denne lista kunne eg ha gjort mykje lenger.

Når eg les, møter eg ein klok, varmhjarta og engasjert forfattar. Fortellingane hans er fiksjon, men har ofte eit realistisk preg, ikkje minst når dei hentar emne frå medisinsk praksis. Dei er ikkje stor skjønnlitteratur, dei er overtydelege i sin bodskap, eg får assosiasjonar til det vi produserte på gymnaset, når eg les. Forfattaren seier 
sjølv at han er takksam for den hjelpa han har fått til å skrive skjønnlitteratur. Kanskje han skulle ha bedt om meir hjelp.

Alt som står i boka, er rett og sant. Det er ikkje ei bok du må lese. Men om du likevel gjer det, vil du kunne risikere å få ny og viktig innsikt om det å vere medmenneske.

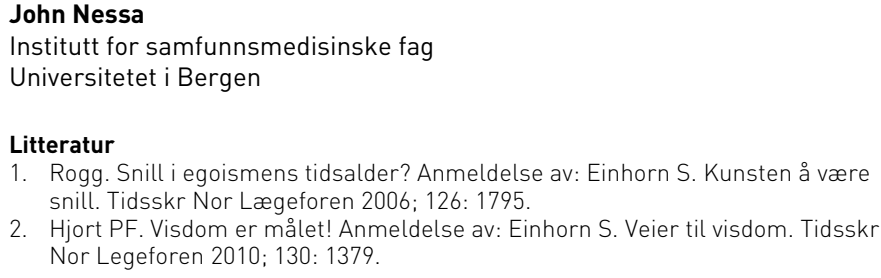

\section{Interessant om Brand}

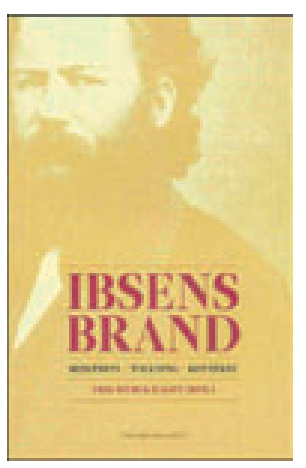

\author{
Erik Bjerck Hagen, red. \\ Ibsens Brand \\ Resepsjon, tolkning, kontekst. $340 \mathrm{~s}$. \\ Oslo: Vidarforlaget, 2010. Pris NOK 299 \\ ISBN 978-82-7990-100-6
}

Ibsens Brand er en antologi som omhandler det dramatiske diktet Brand som ble utgitt i 1866. Boken inneholder en innledning og 11 kapitler og er redigert av litteraturviteren Erik Bjerck Hagen ved Universitetet i Bergen. Til sammen ti forfattere og litteraturforskere har bidratt. Kapitlene er organisert under tre overskrifter: Resepsjon, Tolkning og Kontekst. Vi kjenner Brand som en ung prest med en sterk kallstanke. Han mener at kristendommen er blitt utvannet og krever at tro og liv må henge sammen, og at viljen må være det bærende i menneskers liv. Doktoren spiller en sentral rolle i Brand og er en av dem som går i rette med den steile presten og formaner ham om å være human. «Human! Ja, dette slappe Ord», repliserer Brand.

I innledningskapitlet gjør Bjerck Hagen rede for de ulike hovedretningene i hvordan lesere har oppfattet og vurdert Brand: Lesninger som er heroiserende, lesninger som har sympati med Brand, men som vektlegger hans tragiske feil, kristne lesninger som fordømmer hans hovmod, kritiske lesninger og komiske lesninger. Det er interessant at stykket stadig fremtvinger ulike tolkninger, og Bjerck Hagen konkluderer: «Forbausende få av spørsmålene som har ridd debatten, er nå nærmere noen løsning; forbausende mange engasjerer uavkortet.» Brand er en tekst som pendler mellom komedie og tragedie, og denne sjangerblandingen bidrar til å gjøre teksten mer kompleks og mer åpen for ulike tolkninger, mener Bjerck Hagen. De øvrige bidragene omhandler bl.a. oppsetninger av Brand, hvilken plass stykket har hatt i skolen, viljesproblemet, Brands visjoner, etiske perspektiver og betydningen av landskap og landskapsbeskrivelser i stykket. I tillegg er det tre fortolkninger av stykket i lys av nyere teori.

Antologien er godt forankret i litteraturen og byr på interessant og spennende lesning. Bidragene kan leses uten litteraturfaglig bakgrunn, og de gir leseren et mer reflektert forhold til Brand som litterær skikkelse, og til de ulike måtene man kan forstå ham på. Man får øynene opp for subtile hentydninger, metaforer og symbolikk. Jeg kan anbefale boken for alle som er interessert i Henrik Ibsen.

\section{Angst - avgrunn og avhengighet}

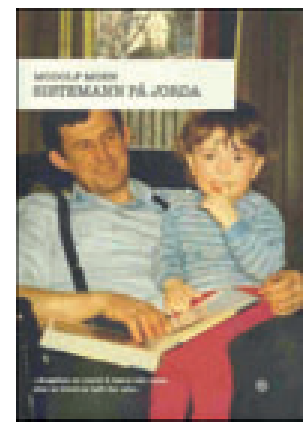

Modolf Moen

Sistemann på jorda

112 s. Oslo: Kagge forlag, 2010. Pris NOK 299

ISBN 978-82-489-0989-7

Møtet med den enkelte pasient gir en annen type innsikt og forståelse av den psykiske lidelsen enn en lærebok. Slik innsikt kan også komme til uttrykk gjennom skjønnlitteraturen hvor forfatterne lar oss bli kjent med sine lidende figurer og deres univers. I debutboken Sistemann på jorda skriver Modolf Moen om sin egen angstfylte barndom.

Boken består av 16 kapitler fordelt på 112 små sider. Forfatteren, som er journalist, veksler mellom avsnitt der han forteller om oppveksten til Modolf i tredje person, og avsnitt der han reflekterer rundt hendelsene i barndommen, og hvordan han nå som 26-åring opplever seg selv og angsten sin.

Tittelen viser til det grunnleggende i lille Modolfs angst, nemlig å skulle bli forlatt uten den tryggheten som foreldrene kan gi ham. Denne separasjonsangsten viser seg i en overdreven bekymring for foreldrenes, og særlig farens, liv og helse. Overnattinger hjemmefra er nærmest utenkelig frem til konfirmasjonsalder, og det samme gjelder det å ligge alene i egen seng gjennom en hel natt. Han blir fysisk syk av å skulle gå i bursdagsselskap. Modolf skjønner etter hvert at han ikke er som alle andre barn, og får en bekymring i tillegg: Skal han aldri bli en vanlig gutt? Det făr ham imidlertid til å bestemme seg for å gjøre noe aktivt for å bli kvitt angsten. Første forsøk er å be til Gud, noe som ikke virker. Deretter vil han utsette seg for farefulle inntrykk gjennom voldelige spill og filmer, en slags herding. Grev Dracula tar nattesøvnen fra ham, men etter hvert tåler han mer og mer, og han får en begynnende følelse av egen kontroll. Han oppdager også at gode skoleprestasjoner gir økt kontroll og følelse av trygghet. Som tenåring tar han mot til seg og klarer å sove alene på gutterommet, i tillegg til at han tør reise på konfirmantleir hvor han til og med oppfører seg litt bøllete.

Forfatteren sporer angstens røtter til avgrunnen i tilværelsen; at vi alle skal dø. Likevel antyder han også at det er noe godt og positivt ved å være redd for å miste menneskene rundt seg, nemlig den gode avhengigheten som gir livet mening.

I tillegg til å gi et fenomenologisk innblikk i separasjonsangst hos en gutt viser forfatteren hvordan det går an å få kontroll over den. Han beskriver erkjennelsen av problemet, beslutningen om å gjøre noe med det og ikke minst ulike varianter av eksponeringstrening.

Boken er en liten og lettlest innføring i noe av angstens fenomenologi hos barn. Jeg kan anbefale den til alle som ønsker å forstå mennesker med usynlige lidelser som angst, bedre.

\section{Ingvar Bjelland}

Klinikk psykisk helsevern for barn og unge

Haukeland universitetssykehus 